\title{
Seismicity distribution and focal mechanism solution of major earthquakes of northern Pakistan
}

\author{
Perveiz Khalid $^{1} \mathbb{D} \cdot$ Asif Ali Bajwa ${ }^{1} \cdot$ Mustansar Naeem $^{1} \cdot$ \\ Zia Ud Din ${ }^{1}$
}

Received: 22 October 2014 / Accepted: 22 June 2015/Published online: 7 July 2015

(C) Akadémiai Kiadó 2015

\begin{abstract}
Pakistan is situated very close to the subduction zone of Indian-Arabian plates and Indian-Eurasian plates. Thus, it is a country with moderate to high seismicity with a large number of major earthquakes. Therefore, the severity of seismic hazards of major earthquakes is not ignorable. The seismicity of northern areas of Pakistan $\left(33-37^{\circ} \mathrm{N}\right.$ and $\left.70-76^{\circ} \mathrm{E}\right)$, which are the part of North West Himalaya, is studied. Three earthquake catalogues are selected and then completed for this purpose. The spatial distribution of their epicenters, as a function of depth, shows that most of the earthquakes (about $84 \%$ ) occurred in shallow to intermediate depths. Relationship between major faults and their source mechanism is also investigated. The Focal mechanism solutions of 39 significant earthquakes in this area, occurred in the period of 1976-2014 with magnitude $M_{w}>5.0$, are also analyzed. The focal depth of these events is in the range of 10-244 km. Among 39 focal mechanisms, the majority of them located in lower crust. Global centroid moment tensor solutions indicate that the majority of the seismic events show strike-slip faulting with a left-lateral sense of motion, followed by thrust and normal faulting. Most of these focal mechanisms located in the HinduKush, a most seismically active, region. The major source of these events and thrusting is the subduction of the Indian plate under the Eurasian Plate. At shallow to intermediate depth, low-to-intermediate angle thrust faulting is dominant. It is seen that in a large number of seismic events the compressive stress is acting nearly in NNW-SSE to N-S directions.
\end{abstract}

Keywords Seismicity · Focal mechanism solution · North Pakistan · b-value

\section{Introduction}

Himalaya mountain range, one of the oldest and active mountain range in the world, is formed by the continuous collision of the Indian-Eurasian plates. Pakistan and adjoining countries, situated in the vicinity of this mountain range, experience high frequency of

Perveiz Khalid

perveiz.geo@pu.edu.pk

1 Institute of Geology, Univeristy of the Punjab, Lahore 54590, Pakistan 
earthquakes, which in some cases have resulted in great loss of lives and destruction (Rafi and Hyder 2012). Northwest (NW) Himalaya is one of the most active seismic regions in the Himalaya mountain range. The northern areas of Pakistan comprise by NW Himalaya. Thus, there are large number of active faults, thrust belts and high seismicity zones

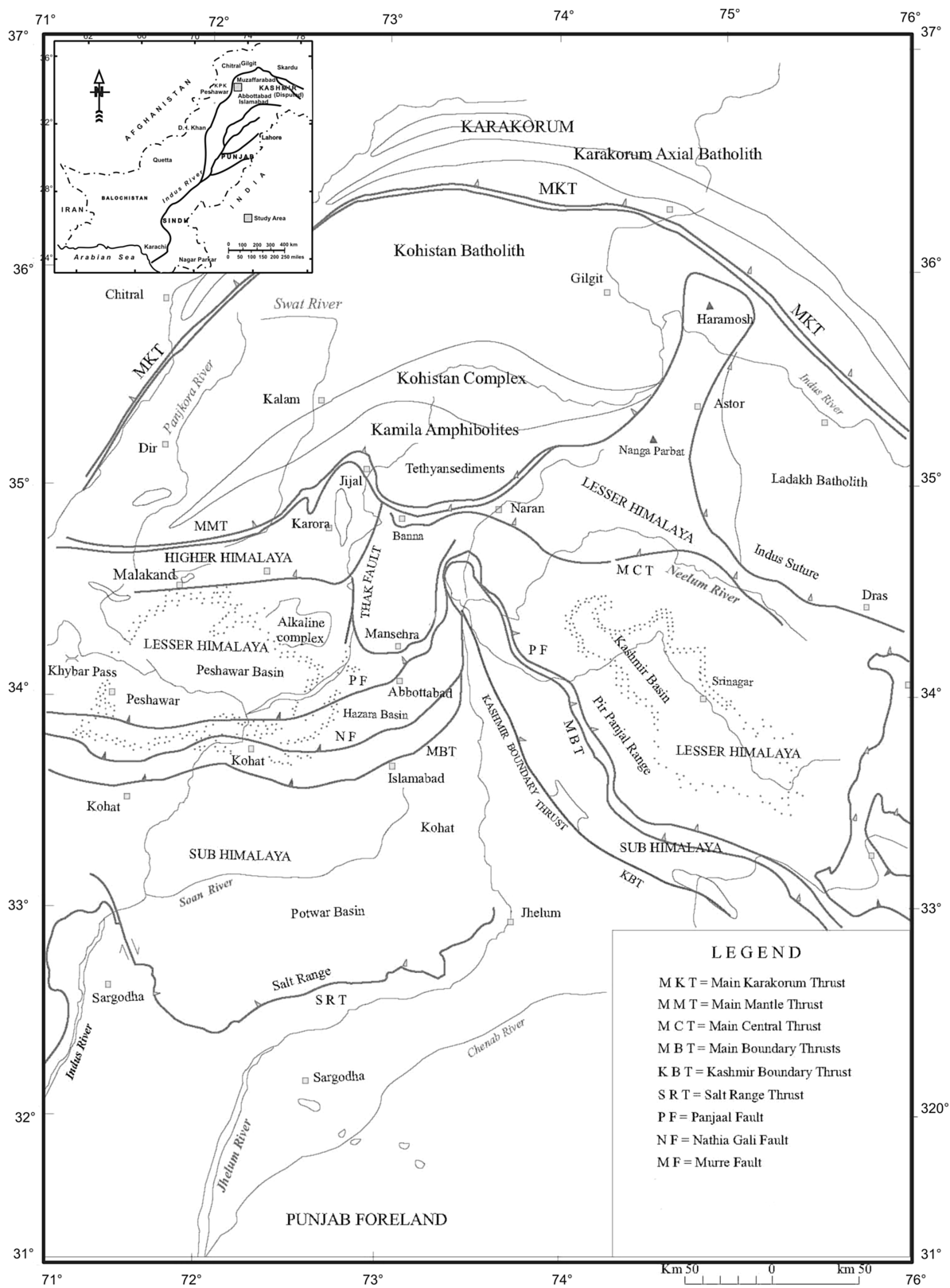

Fig. 1 Simplified tectonic map of northwest Himalaya, Pakistan showing the location of the study area and major geological structurals (after Chaudhry and Ghazanfar 1993) 
(Johnson et al. 1976). Pakistan lies between $23-37^{\circ} \mathrm{N}$ and $61-75^{\circ} \mathrm{E}$ (Fig. 1) and situated on active seismic belts, folds and faults due to the movements of the Indian plate with respect to Eurasia on the west (Kazmi and Jan 1997). The occurrence of moderate to large seismic events in this fold and thrust belt is very common and the result is continuous and active tectonic deformation. Serious damages and large mass destruction is associated with some of the large events through strong ground motion and rupturing the ground surface. Therefore, a proper understanding of seismicity in a particular area is mandatory.

In earthquake seismology, the direction of slip in an earthquake and orientation of faults on which it occurs is called focal mechanism. The orientation of fault planes and slip directions indicated by the focal mechanism solutions can be used to determine stress direction in this region. A seismologist got information from seismograms to see focal mechanism and normally display on maps as a "Beach Ball" symbol (Sipkin 1994). This beach ball describes the direction of slip in an earthquake and the orientation of the fault on which it occurs. The beach ball concept also provides information about nature of fault (strike slip, normal, reverse or oblique fault). The focal mechanism is a result of the direction (positive or negative) of the first P-wave impulse recorded at each station on a large area (Bala et al. 2003).

We have selected high seismicity areas between $33-37^{\circ} \mathrm{N}$ and $70-76^{\circ} \mathrm{E}$ in the north of Pakistan. The location and tectonic map of the study is given in Fig. 1. The main objective of this work is to analyze the seismicity distribution in northern Pakistan since 1900-2014 and the focal mechanism study of some of the significant seismic events with magnitude $\geq 5.0$ from 1976 to 2014. For focal plane solution total 39 earthquakes having magnitude 5.0 or greater are selected from Global CMT catalogue in the study area.

\section{Regional geology and tectonic setting of the area}

The Northern Area of Pakistan (Gilgit-Baltistan) is composed of three, snow-covered mountain ranges: Himalaya, Hindu Kush and Karakoram, which make this region tectonically distinct and unique all over the world. These mountain ranges are the result of collision between the Indian and Eurasian plates at ca. 100 and $50 \mathrm{Ma}$. This collision results in crustal thickening with coeval metamorphism deformation in the rocks of northern area. The northwards movement of Indo-Pakistan sub-plate is continues at the rate of $2 \mathrm{~mm} /$ year (Patriat and Achache 1984). Transpression or strike-slip faulting is also active in this compressional regime (Verma 1991; Sercombe et al. 1998; MonaLisa et al. 2004).

The Indo-Pakistan subcontinent got separated from the Gondwana at ca. $130 \mathrm{Ma}$ (Johnson et al. 1976). Prior to the evolution of plate tectonic model geological arguments were used for the reconstruction of Gondwana. Paleomagnetic data had furnished more credible evidences that were used for the reconstruction of the ancient supercontinents. Owing to Miocene Himalyan orogeny and active convergent regime the area is tectonically highly disturbed (Kazmi and Jan 1997). Consequently, Kohistan (Ladakh), Nanga Parbat contact represents a ductile shear zone (Treloar et al. 1991). The area has outcrops of basement rocks that were formed below the Kohistan Ladakh Island Arc. The Kohistan Magmatic Arc consist of Cretaceous and Tertiary metabasic and sedimentary rocks (Madini et al. 1989) which can be classified into several distinct units on the basis of ages and lithological characteristics (Pudsey 1986). Each of these units extends tens to hundreds of kilometers along the eastern and western side of the arc. From north to south: Yasin group, 
Chalt (and other) Volcanic, Kohistan Batholiths, Jaglot Schist Group, Chilas Complex, Southern Amphibolites and Jijal Complex are exposed in the area (Searle et al. 1999). Volcanic Chalt is more than $350 \mathrm{~km}$ long occurs as Green Stone Complex (Desio and Martina 1972; Zeitler 1985; Petterson and Windley 1985). The volcanics comprised of a diverse group of rocks, ranging from basalt to andesite, dacite and rhyolite flows, conglomerate, breccias and tuff. They exhibit low-grade metamorphism characterized by chlorite, epidote, amphibole, sodic plagioclase, quartz, with or without carbonate, iron oxide and mica (Petterson and Windley 1985). Kohistan batholiths are the principal units of the Kohistan magmatic arc which constitutes $300 \mathrm{~km}$ long and up to $60 \mathrm{~km}$ broad belt to the west of Nanga Parbat. It forms western part of the great trans-Himaliyan Batholiths and continues on the eastern side of Nanga Parbat in Deosai (Kazmi and Jan 1997). The Kohistan batholiths consist of numerous large to small plotons, plugs, dykes and sheets. Most of the rocks of the batholiths display a typical calc-alkaline trend but some rock are tholeiitic, sub-alkaline or even alkaline.

Main Mantle thrust (MMT), Main Karakorum thrust (MKT), Dassu-Sassi Fault, Upper Hunza Fault, Karakoram Fault, Trichmir boundary Fault, Nanga Parbat and Raikot fault are the main tectonic elements present in the area (Fig. 1). MKT also known as the Shyok Suture Zone and MMT is known as Indus Suture Zone (Yeats and Lawrence 1984).

\section{Data source and methodology}

A number of local and international earthquake catalogues are prepared and available for the study area. USGS earthquake database (1900-2014), NESPAK (1962-2014) and Global CMT catalogue for earthquake source mechanisms in and around Pakistan (19762014) were selected for the present analysis and study. The earthquakes recorded in different catalogues have different magnitude scales. This difference in earthquake magnitude scale is primarily because of different recording instruments that were available during recording. Most of the magnitudes in these catalogue were recorded in local magnitude $\left(M_{L}\right)$, which is the oldest magnitude scale defined by Richter (1935), short-period P-wave or body magnitude $\left(m_{b}\right)$ and surface magnitudes $\left(M_{s}\right)$. Therefore, to avoid any fallacious result of our analysis, this inhomogeneity in the magnitude needs to be corrected. All different magnitude needs to transfer to a homogeneous magnitude scale. The homogenization of magnitude of earthquake catalogues is very important to shift all earthquakes in one common magnitude scale to interpret earthquake size characterization and associated phenomenon. In order to homogenize the magnitude, we correlated different magnitude reported for same earthquake recorded in these three catalogues and derived some regionspecific empirical relationship between different magnitude scales (Bormann et al. 2007). In this work, the moment magnitude $\left(M_{w}\right)$ scale is selected as the representative homogeneous scale for each recorded seismic event. Among different available magnitude regression techniques, the least square error minimization technique (Castellaro et al. 2006) is used to establish regression relationship between $M s$ and $M_{w}, M_{L}$ and $M_{w}, m_{b}$ and $M_{w}$. The algebraic relation in the form of

$$
M_{w}=\alpha x+\beta+\varepsilon
$$

is established between different magnitudes with linear correlation (here $x$ is magnitude other than $M_{w}, \alpha$ and $\beta$ are regression parameters and $\varepsilon$ represents to the error). In Fig. 2 moment magnitude is plotted against other magnitudes, taken from NESPAK catalogue, to 

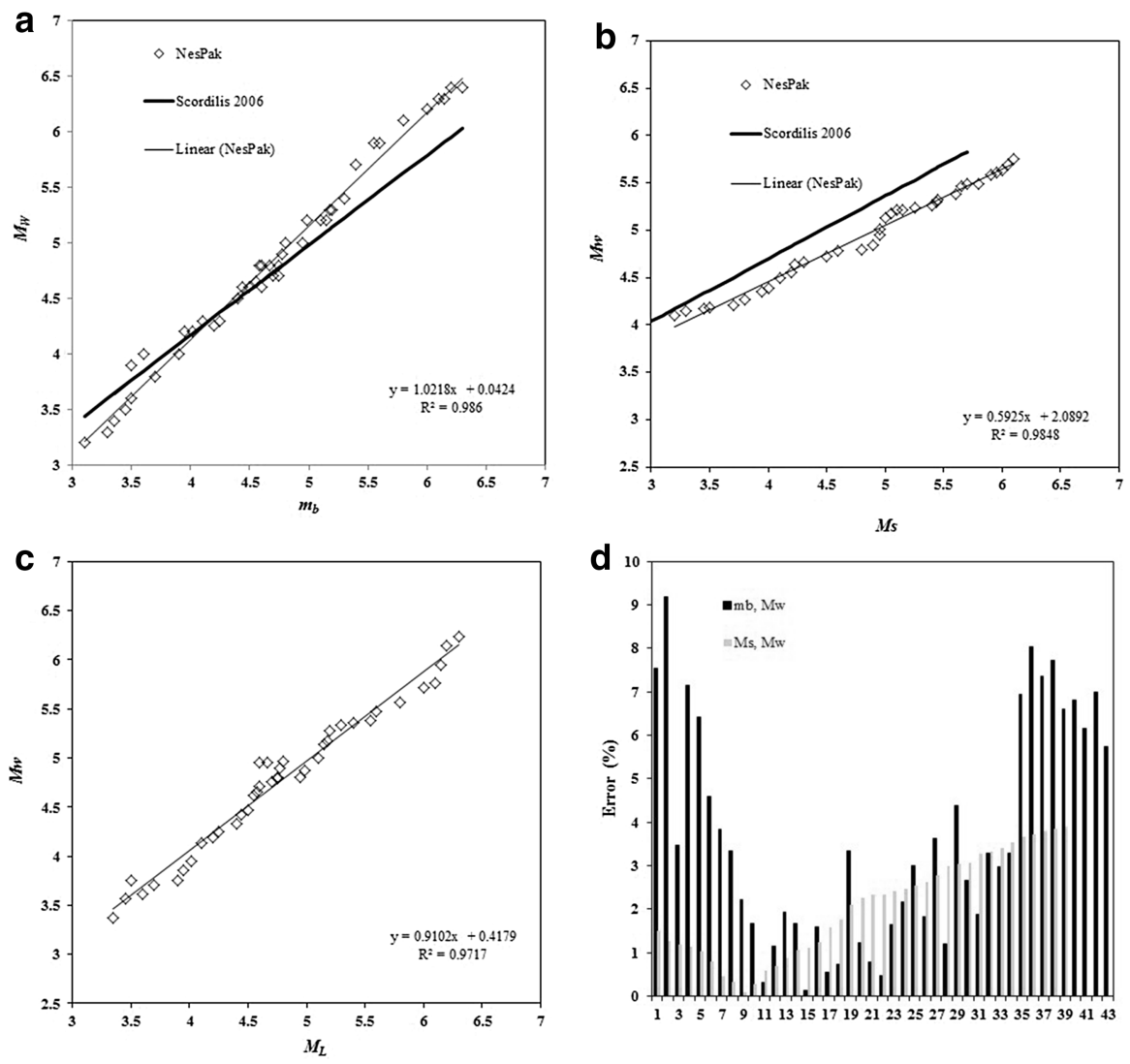

Fig. 2 Linear correlation and error analysis of different magnitude scales in northwest Himalaya and its adjoining areas $\left(33-37^{\circ} \mathrm{N}, 70-76^{\circ} \mathrm{E}\right)$

derive linear regression between different magnitude scales. Theses magnitudes are then compared with the global magnitude relationship proposed by Scordilis (2006) for the conversion of $M s$ and $m_{b}$ to $M_{w}$. A close agreement exists between linear regression and Scordilis proposed relationships. The relative error between linear regression values and Scordilis proposed relationship for different magnitude is very small (Fig. 2d). Different regression parameters of Eq. (1) along with regression coefficient $\left(\mathrm{R}^{2}\right)$ for different magnitudes are given in Table 1. These correlations cover all the events occurred in the depth range of 10-200 km. The correlation for $m_{b}-M_{w}$ is valid for $3.0 \leq m_{b} \leq 6.1, M_{S}-M_{w}$

Table 1 Values of regression parameters $\alpha, \beta$ and regression coefficient $\left(R^{2}\right)$ and number of earthquakes (n) used in magnitude conversion

\begin{tabular}{lllll}
\hline Magnitude conversion & $\alpha$ & $\beta$ & $R^{2}$ & $n$ \\
\hline$m_{b}-M_{w}$ & 1.0218 & 0.0424 & 0.986 & 46 \\
$M_{S}-M_{w}$ & 0.5925 & 2.0892 & 0.985 & 40 \\
$M_{L}-M_{w}$ & 0.9102 & 0.4179 & 0.9717 & 50 \\
\hline
\end{tabular}


for $3.0 \leq M_{S} \leq 5.6$ and $M_{L}-M_{w}$ is valid for $3.2 \leq M_{L} \leq 6.4$. At higher magnitudes above these limits, some discrepancy between linear regression and data points is observed.

After the homogenization of the magnitudes, all duplicated earthquakes from these three catalogues are merged into a single entry for each earthquake event. Total 15,000 unduplicated seismic events have been selected in the study area bounded between $33-37^{\circ} \mathrm{N}$ and $70-74^{\circ} \mathrm{E}$. All these events have magnitude greater or equal to 3.0 and recorded in more than one catalogue. However, for focal mechanism solution 39 seismic events having $M_{w} \geq 5.0$ were selected in the study area for the period of 1976-2014. Location and other characteristics of these earthquakes are listed in Table 2.

\section{Seismicity distribution}

Based on depth of occurrence and magnitude, earthquake distribution is random throughout the region, starting from shallow to deep $(>300 \mathrm{~km})$ as shown in Fig. 3. The seismicity pattern of the region shows that whole area under investigation is seismically active. The seismic activity is concentrated mostly in northern parts of Pakistan. The majority of earthquakes recorded in the region originate from highly active Hindu Kush region which is represented by high concentration of earthquakes. In central part of the country most of the events are of shallow origin $(<50 \mathrm{~km})$, however, in northern part of the country, the seismic events occurred at shallow as well as deeper depth. Most of the northern part, the HinduKush and Kashmir region have intermediate to deeper seismic events encompassing depth range 100-300 km. Total 22 seismic events documented in USGS catalog having magnitude $M_{w} \geq 7.0$. Most of the earthquakes occurred in Hindu-Kush region with deeper depth. Kashmir earthquake of October 2005, have 7.6 magnitude and $12 \mathrm{~km}$ depth.

The histogram of the number of seismic events as a function of depth in the study area is presented in Fig. 4a. The distribution on depth concentrated into three zones of seismicity: shallow depth of crustal domain 0-35 km, upper part of subduction zone (intermediate depth) at depth of 80-120 km and the lower part of subduction zone (deeper events) at depth range of 180-225 km. In crustal domain, the maximum number of earthquakes occurred at shallow depth between 10 and 15 and $35-40 \mathrm{~km}$ whereas the seismicity decreased at $15-30 \mathrm{~km}$ depth. At shallow depth, about $20 \%$ of the total recorded earthquakes are concentrated into two narrow zones: one is $10-15 \mathrm{~km}$ hypocentral depth and second is $30-35 \mathrm{~km}$ depth. The first narrow band of earthquakes followed the curved Himalayan front. This seismicity originated by the deformation between upper and lower crust at a ramp under the Lesser and Higher Himalaya (Pandey et al. 1999). The second band indicates the seismic events generated by the subduction of the Indian plate under Eurasian plate. However, most the earthquakes are of low to intermediate magnitudes as shown in Fig. 4b. Only two earthquakes of magnitude above 7 were generated from the deformational zone.

To quantify the seismicity distribution in time and space domain, Gutenberg and Richter (1954) relation

$$
\log _{10} N(M)=a-b M
$$

is used for the period of 62 years (1952-2014). Here $N(M)$ is the number of earthquakes having magnitude equal or greater than $M$ occurring annually in a specific area, $a$ and $b$ are coefficients termed as seismicity parameters of that area. The frequency-magnitude curve is shown in Fig. 5. From this magnitude-frequency curve, $a$ and $b$ coefficients of Eq. (3) were determined for this area. From regression analysis following frequency-magnitude relationship is drawn. 
Table 2 Source mechanism of significant events of Northern Pakistan from Global CMT catalogue (1976-2014)

\begin{tabular}{|c|c|c|c|c|c|c|c|c|c|c|c|}
\hline & Date & $M_{w}$ & $\begin{array}{l}\text { Depth } \\
(\mathrm{km})\end{array}$ & $\begin{array}{l}\text { Latitude } \\
\left({ }^{\circ} \mathrm{N}\right)\end{array}$ & $\begin{array}{l}\text { Longitude } \\
\left({ }^{\circ} \mathrm{E}\right)\end{array}$ & $\begin{array}{l}\text { Strike }^{\circ} \\
1\end{array}$ & $\begin{array}{l}\text { Strike }^{\circ} \\
2\end{array}$ & $\begin{array}{l}\operatorname{Dip}^{\circ} \\
1\end{array}$ & $\begin{array}{l}\operatorname{Dip}^{\circ} \\
2\end{array}$ & $\begin{array}{l}\operatorname{Slip}^{\circ} \\
1\end{array}$ & $\begin{array}{l}\operatorname{Slip}^{\circ} \\
2\end{array}$ \\
\hline 1 & $9 / 12 / 1981$ & 6.1 & 10 & 73.48 & 35.22 & 107 & 36 & 79 & 300 & 54 & 98 \\
\hline 2 & 11/20/1982 & 5.7 & 10 & 70.35 & 34.46 & 259 & 28 & 109 & 57 & 63 & 80 \\
\hline 3 & 2/1/1984 & 6.1 & 15 & 70.05 & 34.19 & 268 & 37 & 121 & 50 & 59 & 69 \\
\hline 4 & 7/17/1986 & 5.6 & 97 & 71.13 & 36.47 & 205 & 46 & 1 & 114 & 89 & 136 \\
\hline 5 & $7 / 20 / 1988$ & 5.5 & 15 & 72.83 & 36.91 & 137 & 38 & -96 & 324 & 53 & -86 \\
\hline 6 & $2 / 20 / 1998$ & 6.3 & 244 & 70.88 & 36.5 & 184 & 15 & 100 & 354 & 75 & 87 \\
\hline 7 & $11 / 1 / 2002$ & 5.3 & 33 & 74.64 & 35.56 & 216 & 42 & -90 & 36 & 48 & -90 \\
\hline 8 & $11 / 3 / 2002$ & 5.3 & 17 & 74.7 & 35.1 & 45 & 30 & -69 & 201 & 62 & -102 \\
\hline 9 & $11 / 20 / 2002$ & 6.3 & 15 & 74.66 & 35.52 & 204 & 30 & -117 & 55 & 64 & -75 \\
\hline 10 & 2/14/2004 & 5.4 & 12 & 73.22 & 34.75 & 111 & 49 & 57 & 336 & 51 & 122 \\
\hline 11 & $2 / 14 / 2004$ & 5.3 & 19 & 73.12 & 34.78 & 339 & 40 & 119 & 123 & 56 & 68 \\
\hline 12 & $10 / 8 / 2005$ & 7.6 & 12 & 73.47 & 34.38 & 334 & 40 & 123 & 114 & 57 & 65 \\
\hline 13 & $10 / 8 / 2005$ & 6.4 & 12 & 73.12 & 34.7 & 328 & 39 & 107 & 127 & 53 & 77 \\
\hline 14 & $10 / 8 / 2005$ & 5.5 & 12 & 73.1 & 34.68 & 8 & 41 & 118 & 153 & 54 & 68 \\
\hline 15 & $10 / 9 / 2005$ & 5.7 & 12 & 73.13 & 34.65 & 344 & 37 & 121 & 127 & 59 & 69 \\
\hline 16 & $10 / 12 / 2005$ & 5.3 & 12 & 73.08 & 34.88 & 315 & 42 & 97 & 126 & 49 & 84 \\
\hline 17 & $10 / 19 / 2005$ & 5.6 & 12 & 73.05 & 34.76 & 303 & 31 & 105 & 106 & 60 & 81 \\
\hline 18 & $10 / 23 / 2005$ & 5.4 & 12 & 73.03 & 34.74 & 307 & 32 & 110 & 105 & 60 & 78 \\
\hline 19 & $4 / 3 / 2007$ & 6.2 & 223 & 70.62 & 36.53 & 30 & 32 & 141 & 155 & 71 & 64 \\
\hline 20 & $5 / 11 / 2008$ & 5.4 & 218 & 70.62 & 36.38 & 282 & 22 & 103 & 88 & 68 & 85 \\
\hline 21 & $9 / 5 / 2008$ & 5.4 & 225 & 71.12 & 36.52 & 205 & 26 & 72 & 44 & 65 & 98 \\
\hline 22 & 9/6/2008 & 5.8 & 183 & 70.78 & 36.49 & 85 & 18 & 14 & 250 & 72 & 85 \\
\hline 23 & $10 / 26 / 2008$ & 5.7 & 200 & 70.46 & 36.44 & 273 & 18 & 87 & 97 & 72 & 91 \\
\hline 24 & $12 / 29 / 2008$ & 5.8 & 155 & 70.91 & 36.48 & 92 & 29 & 94 & 267 & 61 & 88 \\
\hline 25 & $1 / 4 / 2009$ & 5.7 & 190 & 70.65 & 36.46 & 282 & 35 & 131 & 55 & 65 & 66 \\
\hline 26 & $2 / 20 / 2009$ & 5.5 & 18 & 73.79 & 34.14 & 308 & 21 & 99 & 118 & 70 & 87 \\
\hline 27 & $10 / 22 / 2009$ & 6.1 & 181 & 70.82 & 36.51 & 83 & 41 & 99 & 252 & 49 & 82 \\
\hline 28 & $10 / 29 / 2009$ & 6.2 & 219 & 70.66 & 36.39 & 282 & 25 & 75 & 119 & 66 & 97 \\
\hline 29 & $9 / 17 / 2010$ & 6.2 & 208 & 70.79 & 36.44 & 261 & 32 & 117 & 50 & 61 & 74 \\
\hline 30 & 3/21/2011 & 5.8 & 194 & 70.73 & 36.47 & 292 & 32 & 134 & 63 & 67 & 67 \\
\hline 31 & $5 / 14 / 2011$ & 6 & 210 & 70.62 & 36.45 & 281 & 21 & 72 & 121 & 70 & 97 \\
\hline 32 & $11 / 7 / 2011$ & 5.7 & 222 & 71.02 & 36.59 & 161 & 36 & 88 & 343 & 54 & 91 \\
\hline 33 & $3 / 12 / 2012$ & 5.7 & 22 & 73.24 & 36.88 & 212 & 53 & -35 & 324 & 63 & -137 \\
\hline 34 & $7 / 12 / 2012$ & 5.8 & 192 & 70.76 & 36.47 & 73 & 28 & 77 & 268 & 63 & 97 \\
\hline 35 & $12 / 29 / 2012$ & 5.6 & 119 & 70.43 & 35.57 & 291 & 36 & 136 & 60 & 66 & 63 \\
\hline 36 & 4/4/2013 & 5.4 & 241 & 70.97 & 36.4 & 262 & 34 & 129 & 38 & 64 & 67 \\
\hline 37 & $4 / 24 / 2013$ & 5.5 & 104 & 70.45 & 34.41 & 200 & 46 & 153 & 310 & 71 & 47 \\
\hline 38 & $5 / 1 / 2013$ & 5.6 & 20 & 75.6 & 33.02 & 328 & 23 & 113 & 124 & 69 & 81 \\
\hline 39 & 9/8/2013 & 5.2 & 215 & 70.02 & 36.55 & 230 & 15 & 42 & 100 & 80 & 101 \\
\hline
\end{tabular}




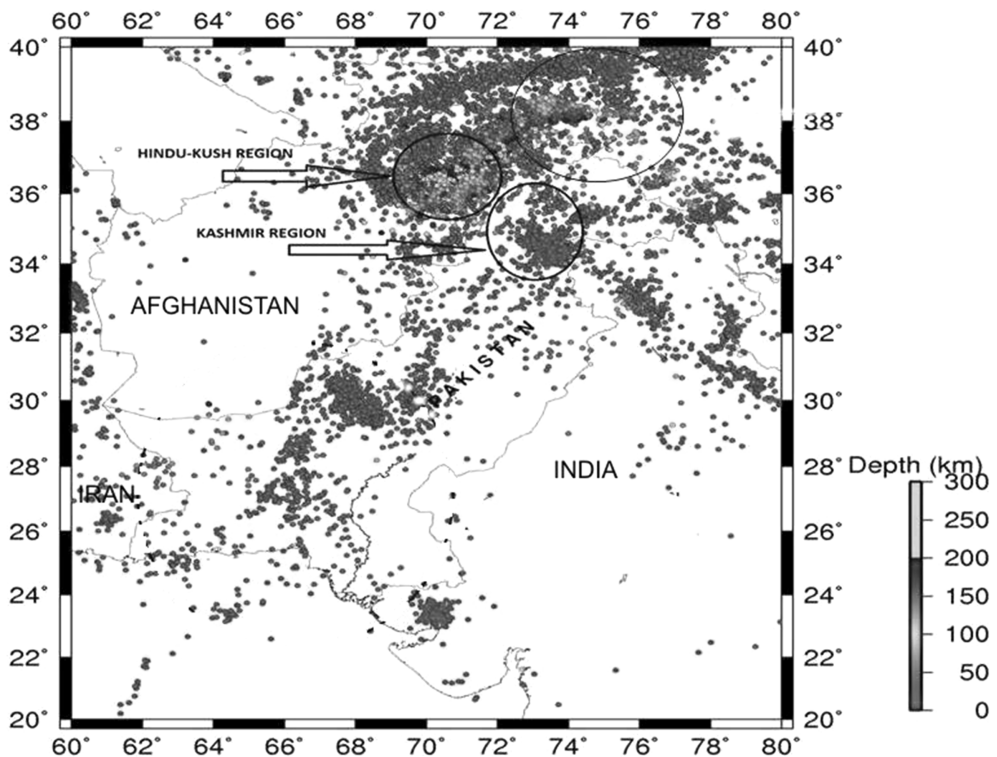

Fig. 3 Seismicity distribution of Pakistan and its surrounding countries from 1900 to 2014
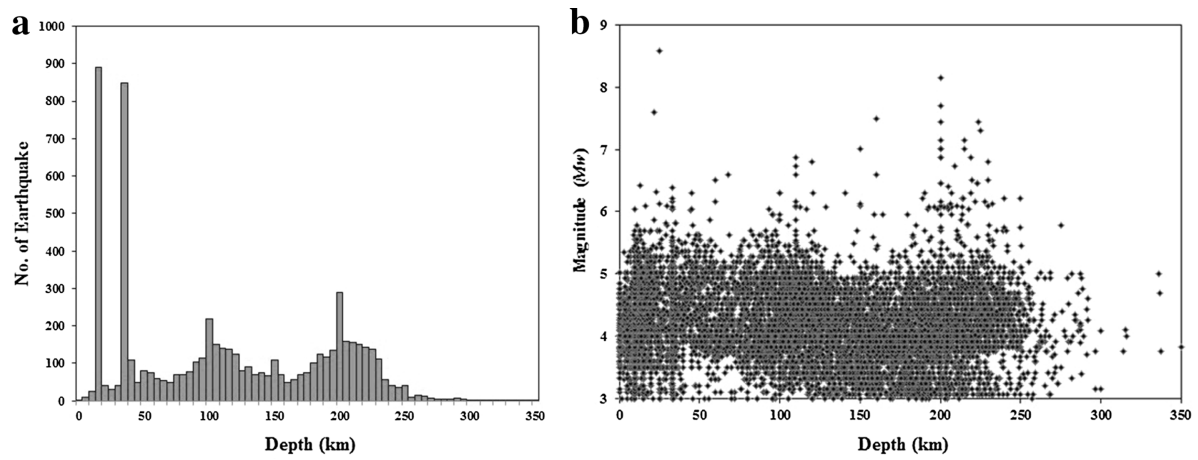

Fig. 4 a Histogram showing depth versus frequency distribution of earthquakes in northern Pakistan (33-37 $\left.\mathrm{N}, 70-76^{\circ} \mathrm{E}\right)$ by using USGS catalogue (1900-2014). b Depth versus magnitude graph showing the seismicity and hypocentral depth of the earthquakes in the area under investigation

$$
\log _{10} N(M)=5.665-0.9271 M
$$

The b-value is close to 1 , which is its global value.

\section{Focal mechanism solution}

For depth distribution and fault plane analysis of significant earthquakes in study area, Global CMT focal mechanism solution is used. The focal mechanism map of all significant seismic events, having magnitude equal or greater than 5.0 for the period of 1976-2014, is shown in Fig. 6. The orientation of these beach balls shows intense thrusting in the area. 


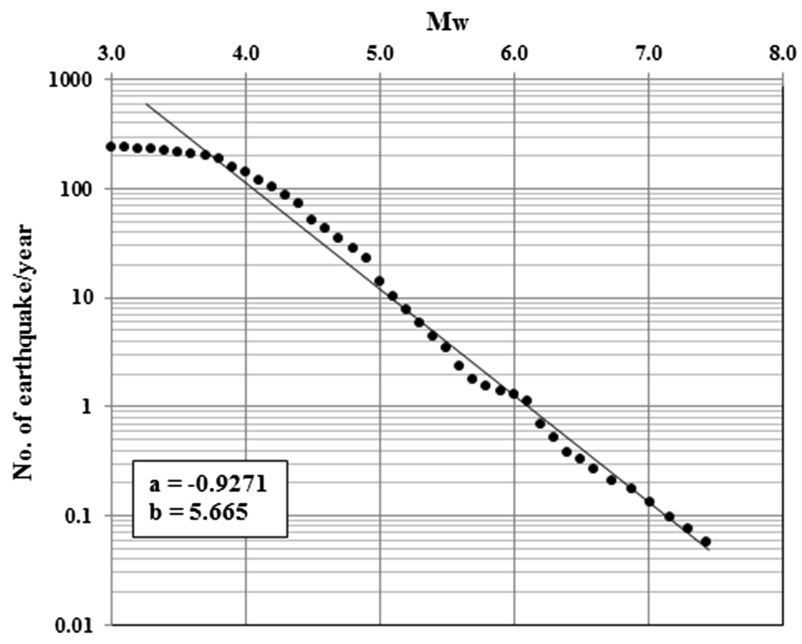

Fig. 5 Frequency magnitude distribution of earthquakes in northern Pakistan $\left(33-37^{\circ} \mathrm{N}, 70-76^{\circ} \mathrm{E}\right)$

Strike-slip and reverse faulting is also reported in this area. It is clear from figure that majority of these mechanisms originated from or near to the major geological structures. The detailed geological description is given in Fig. 1. Based on focal depth of each event, these focal mechanisms can be divided into three depth intervals as mentioned in Fig. 4a:

(i) $\quad 0-35 \mathrm{~km}$ (shallow, crust).

(ii) $\quad 80-120 \mathrm{~km}$ (intermediate, upper subduction zone).

(iii) $\quad 180-250 \mathrm{~km}$ (deep, lower subduction zone).

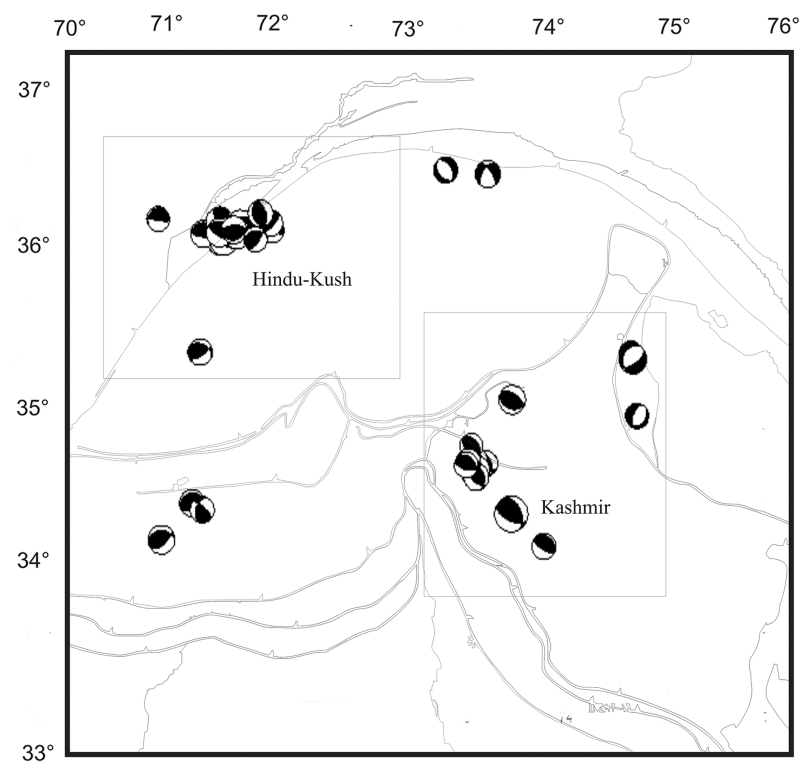

Fig. 6 Focal mechanism solutions of 39 major earthquakes $\left(M_{w} \geq 5.0\right)$ in the study area from the period of 1976-2014. See Fig. 1 for legends and detailed tectonic setting along with geological structures of this area 
Table 2 summarizes source mechanism of some major earthquakes of northern Pakistan. Among 39 focal mechanisms, 19 occurred at shallow depths, 16 are located at deep and merely 4 occurred at intermediate depths. As evident from Fig. 3, most of the seismic events occurred in the Hindu-Kush region are deeper than that of Kashmir area due to the proximity with subduction of Indian plate under Eurasian plate. Based on their distribution and location, these mechanisms can be divided into two zones: Hindu-Kush and Kashmir. However, few FSM do not exist in these zones. In the east of Hindu-Kush region, near to Main Karakorum Thrust, Two mechanisms, which are not included in both zones, were also generated from the MKT. One of them showing normal strike-slip fault, while other is oblique dip-slip normal fault. Three FSM between the Higher and Lesser Himalaya show oblique dip slip reverse fault. These were generated at the ramp between the Higher Himalaya and Lesser Himalaya.

\subsection{FMS in Hindu-Kush region}

A total 21 out of 39 seismic events occurred in the Hindu-Kush region, which is the most seismically active zone. Majority of these mechanism solutions are located along the MKT and showing NNW-SSE to N-S directions of faulting. Most of the solutions indicate reverse dip-slip faulting along the auxiliary plane. However, few represents oblique strikeslip fault. Focal depth of these events indicates that the cover rock beneath the Hindu-Kush region is affected by these earthquakes.

\subsection{FMS in Kashmir region}

11 focal mechanisms among total 39 are located in Kashmir region. Most of these mechanisms are situated near to MBT. The orientation of beach ball diagrams shows that these mechanisms follow NNW-SSE to N-S directions of faults. All these are thrust and reverse faults. However, two FSM away from Main Boundary thrust (MBT), near to MMT show normal faulting.

\section{Conclusions}

On the basis of three earthquake catalogues: USGS, NESPAK and Global CMT, we have analyzed the seismicity distribution and focal mechanism solution of northern Pakistan, covering the time interval of 1900-2014, in connection with active tectonics. The focal depth distribution of the earthquakes is very random. However, the Hindu-Kush region is most active region. Majority of the major earthquakes have shallow to intermediate focal depth. Frequency of earthquakes in Hindu-Kush region is greater but due to deeper and intermediate earthquake events these regions have less damaging effects. While frequency of earthquakes is low in Kashmir region but due to shallow depth events these regions have maximum damaging effects. Total 39 focal mechanism solutions of major earthquakes are also analyzed. We draw beach balls of 39 significant events having magnitude equal or greater than 5.0 in the study area. The focal mechanism shows that in study area, HinduKush and Kashmir regions mostly show the thrust faulting mechanisms occasionally show normal faulting. The direction of crustal stress in Kashmir is NE-SW which is the perpendicular to the line of the plate collision and Main Boundary Thrust. Subduction of the Indian plate under the Eurasian Plate is a source of some of the major events with thrusting 
and reverse faulting. Low-to-intermediate angle thrust faulting is dominant to a depth of $40-70 \mathrm{~km}$.

\section{References}

Bala A, Radulian M, Popescu E (2003) Earthquakes distribution and their focal mechanism in correlation with the active tectonic zones of Romania. J Geodyn 36:129-145

Bormann P, Liu R, Ren X, Gutdeutsch R, Kaiser D, Castellaro S (2007) Chinese national network magnitudes, their relation to NEIC magnitudes, and recommendations for new IASPEI magnitude standards. Bull Seismol Soc Am 97:114-127

Castellaro S, Mulargia F, Kagan YY (2006) Regression problems for magnitudes. Geophys J Int 165:913-930

Chaudhry MN, Ghazanfar M (1993) Some tectonostrtigraphic observations on northwest Himalaya, Pakistan. Pak J Geol 1-2:1-19

Desio A, Martina E (1972) Geology of the upper Hunza valley, Karakorum, west Pakistan. Boll Soc Geol Ital 91:283-314

Gutenberg B, Richter CF (1954) Magnitude and energy of earthquakes, 2nd edn. Princeton Press

Johnson GD, Powel CMA, Veevers JJ (1976) Spreading history of the eastern Indian Ocean and greater Indians northwards light from Antartica and Australia. Geol Soc Bull Am 87:1560-1566

Kazmi AH, Jan MQ (1997) Geology and tectonics of Pakistan. Graphics Pubishers, Karachi

Madini P, Lawrence RD, UR-Rehman S (1989) The northwest Nanga Parbat-Haramosh Massif; evidence for crustal uplift at the northwestern corner of the Indian. Geol Soc Am Spec Pap 232:169-182

MonaLisa Khan SA, Khwaja AA (2004) Focal mechanism studies of north Potwar deformed zone (NPDZ), Pakistan. Acta Seismol Sin China 17:255-261

Pandey MR, Tandukar RP, Avouac JP, Vergne J, Heritier T (1999) Seismotectonics of the Nepal Himalaya from a local seismic network. J Asian Earth Sci 17:703-712

Patriat P, Achache J (1984) Indian-Eurasia collisional chronology and its implications for crustal shortening and driving mechanism of plates. Nature 311:615-621

Petterson M, Windley FB (1985) Rb-Sr dating of the Kohistan arc-batholith in the Trans-Himalaya of north Pakistan, and tectonic implications. Earth Plan Sci Lett 14:45-57

Pudsey CJ (1986) The Northern suture in Pakistan: margin of Cretaceous island arc. Geol Magzine 123:405-423

Rafi Z, Hyder A (2012) Seismic hazard analysis and zonation for the northern areas of Pakistan and Kashmir. Report by Pakistan Meteorological Department, pp 1-62

Richter CF (1935) An instrumental earthquake magnitude scale. Bull Seismol Soc Am 25:1-31

Scordilis EM (2006) Empirical global relations converting $M_{S}$ and $m_{b}$ to $M_{w}$. J Seismol 10:225-236

Searle MP, Khan MA, Fraser JE, Gough SJ, Jan MQ (1999) The tectonic evolution of the KohistanKarakoram collision belt along the Karakoram Highway transect, north Pakistan. Tectonics 18:929-949

Sercombe WJ, Pivnik DA, Wilson WP, Albertin ML, Beck RA, Stratton MA (1998) Wrench faulting in the northern Pakistan foreland. AAPG Bull 82:2003-2030

Sipkin SA (1994) Rapid determination of global moment-tensor solutions. Geophys Res Lett 21:1667-1670

Treloar PJ, Potts JG, Wheeler J, Rex DC (1991) Structural evolution and asymmetric uplift of the Nanga Parbat syntaxis. Geol Rundsch 80:411-428

Verma RK (1991) Seismicity of the Himalaya and the northeast India, and nature of continent-continent collision. Phys Chem Earth 18:345-370

Yeats RS, Lawrence RD (1984) Tectonics of the Himalayan thrust belt in northern Pakistan. In: Haq BU, Milliman JD (eds) Marine geology and oceanography of the Arabian Sea and coastal Pakistan. New York, Van Nostrand Reinhold, p 117-198

Zeitler PK (1985) Cooling history of the NW Himalaya, Pakistan. Tectonics 4:127-151 